\title{
RĪGAS PILSĒTAS VADĪBAS UN NEVĀCU AMATU ATTIEKSME PRET SABIEDRISKAJĀM KLAUŠĀM NO 18. GS. VIDUS LİDZ 19. GS. SĀKUMAM*
}

\section{Anita Čerpinska}

Dr. hist., Latvijas Universitātes Latvijas vēstures institūta pētniece. Zinātniskās intereses: Rīgas vēsture 18. gs. un 19. gs. pirmajā pusē.

Raksts veltīts sabiedrisko klaušu jautājumam Rīgas pilsētā un to interpretācijai tiesu materiālos. Rāte klaušas uzdeva veikt nevācu amatiem par velti vai nelielu atlīdzību. Klaušas bija saistītas ar ugunsdrošību un aizsardzību pret plūdiem, satiksmes un sakaru nodrošināšanu, kā arī tīrības un kārtības uzturēšanu. Tām bija ārkārtas un sezonāls raksturs. Sākot ar 18. gs. 30. gadiem, sabiedrisko klaušu uzlikšanu nevācu amatiem pilsētas vadība un birǵgeri izmantoja kā argumentu, norādot uz amatu locekḷu zemāko statusu pilsētas kopienā. Atbildes reakcija uz to bija amatu sūdzēšanās augstākās instancēs par klaušu uzlikšanu un lūgumi darbus apmaksāt vai atcelt.

Atslēgas vārdi: onera publica, Rīgas birǵeru kopiena, Rīgas nevācu amati, attieksme pret darbu.

18. gs. otro pusi un 19. gs. sākumu pien̦emts uzskatīt par plašu pārmaiṇu laiku, lūzuma posmu starp dažādiem laikmetiem Eiropas vēsturē. Apgaismotāji proponēja ideju par cilvēka un sabiedrības spēju attīstīties, ja tiek nodrošināti labvēlīgi apstākḷi. Liela daḷa Eiropas zemju piedzīvoja plašas tiesiskās sistēmas un valsts pārvaldes reformas. To mērḳi bija dažādi, tāpat kā rezultāti, bet šajā pārmaiṇu posmā sāka veidoties priekšstats par sabiedrību kā pilsoṇu kopienu. ${ }^{1}$

* Raksts tapis LU Bāzes un snieguma finansējuma projekta Nr. AAP2016/ B060 "Letonika, diaspora un starpkultūru komunikācija" apakšprojekta "Latvijas teritorija kā dažādu kultūrtelpu, relig̣iju, politisko, sociālo un ekonomisko interešu saskarsmes zona no aizvēstures līdz mūsdienām" ietvaros. 
Vēsturnieks Lotārs Galls norādījis, ka, sākot ar 18. gs., uz kārtu principu balstītās sabiedrības hierarhiskās struktūras mainījās ḷoti lēnām, bet galvenā iezīme, kas pirmā parādīja nozīmīgu pārmaiṇu sākumu, bija sabiedrības nodarbinātības (profesionālā) struktūra un zināma "karjeras kāpuma" iespēja, lai gan sākumā l̦oti ierobežota. Tas nojauca kārtu sabiedrībai tik raksturīgo ciešo saikni starp izcelšanos un nodarbošanos. Pakāpeniski profesija kḷuva par faktoru, kas noteica cilvēka sociālo eksistenci, statusu un pašnovērtējumu. Tas bija aizsākums virzībai uz individuālismu un izpratni, ka katrs atrod savu vietu, balstoties uz talantiem, centību un darba augḷiem. ${ }^{2}$ Apgaismības priekšstats par ideālo cilvēku, kura sūtība ir izmantot savas spējas sabiedrības labā, izraisīja lēnu, bet pilnīgu jēdziena "darbs" izpratnes maiņu. ${ }^{3}$

Minētās pārmaiṇas nevarēja neatbalsoties arī Latvijas vēsturē, lai gan vienmēr būs jautājums par to, kādos procesos pārmaiṇas var novērot izteiktāk un kādos - mazāk izteikti. Šì raksta mērḳis ir caur sabiedrisko klaušu prizmu palūkoties uz Rīgas pilsētas vadības, birğeru un nevācu amatu attieksmi pret šiem darbiem, mēǵinot konstatēt pārmaiņu klātesamību un to iemeslus. Lai sasniegtu šo mērḳi, rakstā apskatīti vairāki jautājumi:

1) kas bija sabiedriskās klaušas;

2) vai un cik lielā mērā klaušu veikšana atspoguḷota amatu darbību organizējošos dokumentos, kādus darbus ietvēra nevācu amatu veiktās sabiedriskās klaušas;

3) kādos tiesāšanās procesos parādās sabiedrisko klaušu jautājums;

4) kāda ir sabiedrisko klaušu interpretācija strīdos, kur tās bijušas galvenais iemesls.

Rakstā izceltās pilsētas sabiedrības daḷas ir pilsētas vadība un birǵeri, no vienas puses, un nevācu amati jeb tirdzniecības palīgamati, no otras. Izmantojot iepriekšējos gadsimtos skaidri izstrādātus regulējumus darba, tirgus, nodokḷu sistēmas, kopā sadzīvošanas un religiskās prakses apstākḷiem, 18. gs. pilsēta, arī Rīga, turpināja iesākto praksi pilsētas pārvaldīšanā un pieṇemto nosacījumu izpildi kontrolēja policejiskiem līdzekḷiem. ${ }^{4}$ Pilsētas vadība uzskatijja, ka tā aizstāv visu vietējo amatu tiesības uz viṇu nodarbošanos, tādējādi nodrošinot iztiku un labklājību, pretī prasot noteiktus darbus pilsētas labā. 
Otra rakstā iesaistītā pilsētas sabiedrības kopa ir birǵeri jeb tirgotāji un cunftēs apvienotie amatnieki, kuriem bija piešķirtas birgeru tiesības, kas deva viṇiem vairākas priekšrocības - tiesības tirgoties vai nodarboties ar amatiem, tiesības piedalīties pilsētas pārvaldē. Birǵeri mēdza iesaistīties strīdos ar nevācu kopienu par tiesību jautājumiem un kā argumentu tajos izmantoja tieši amatu veiktos sabiedriskos pienākumus pilsētas labā. Rāte un tās tiesu instances sastāvēja tikai no birgeriem, tomēr kā administratīvai iestādei rātei daudz lielākā mērā nekā birg̣eru kopienai bija jārēḳinās ar valdības nostāju dažādos jautājumos. Rāte atsevišķos strīdos darbojās kā moderators starp nevācu amatu locekḷiem un birgeru kopienu, bieži nostājoties birǵeru pusē. Citos strīdos pilsēta pati bija iesaistīta kā apsūdzētā vai apsūdzētāja.

Par nevāciem plašākā kontekstā pilsētas vēstures attiecīgā laika avotos mēdza dēvēt visu nebirǵeru kopienu, tātad to pilsētas sabiedrības daḷu, kurai nebija birǵeru tiesību. Rakstā nav runāts par nebirǵeru vai nevācu kopienu kopumā, bet tikai par nevācu amatiem, jo nebirğeru vai nevācu kopienai netika uzdotas sabiedriskās klaušas. Tirdzniecībā iesaistītie vietējie un nevācu amati 18. gs. bija ozolkoku šķirotāji (biedru skaits 1763. g. - 12), ormaņi (12), mastu šķirotāji (7 meistari, 38 zellıi), enkurnieki (19), pārcēlāji (80), zvejnieki ${ }^{5}$ (50-100), vīna nesēji (10), sāls nesēji (27), lig̣eri (labības, linu un kaṇepju sēklu transportētāji, mērītāji un apstrādātāji, 63, bet ir norādes arī par 128), kaņepāju kulstītāji (56), loči (1742. g. 16). ${ }^{6}$ Vèlāk tiem pievienojās sāls un labības mērītāju amats, kurā 1816. gadā bija 45 biedri un kurā iekḷāvās sāls nesēji. ${ }^{7}$ Katrs amats tirdzniecības sezonā nodarbināja vairākus simtus algādžu. ${ }^{8}$ Lìdzīgas brālības vai profesionālu kopas, kas nodarbojās ar zveju vai preču transportēšanu, pastāvēja arī Tallinā, Dancigā, Rostokā u.c. ${ }^{9}$

Raksta izstrādē izmantotie avoti lielākoties glabājas Latvijas Nacionālā arhīva Latvijas Valsts vēstures arhīva (LNA-LVVA) fondos, un tos var iedalìt divās grupās:

1) amatu statūti, ar tiem saistītie noteikumi un amatu grāmatas;

2) Rīgas tiesu materiāli - ieraksti tiesu protokolu grāmatās, oficiālā sarakste, kas saistīta ar tiesāšanās procesiem.

Nevācu amatu organizācijas noteikumus mēdza saukt par statūtiem, šrāgām vai reglamentiem, atkarībā no to pieņemšanas laika. Tie bija amata darbības pamatdokumenti, arī privilēgijas, tāpēc 
svarīgi noskaidrot, vai un cik lielā mērā sabiedrisko klaušu pildīšana norādīta šì tipa dokumentos. Nolikumi nemainījās bieži. Piemēram, zvejniekiem, alus nesējiem un sāls nesējiem 18. gs. vēl joprojām bija aktuāli 15 . gs. statūti, bet ligereriem - 1740. gada statūti. Izṇēmums ir pārcēlāju amats, kura pirmais nolikums izstrādāts 1763. gadā, kaut gan pārcēlāji darbojušies jau 17. gadsimtā. 1763. gada reglaments piedzīvojis nelielas izmaiņas, bet būtiski mainīts 1798. gadā (aktuāls līdz 1823. g.), lai gan sabiedrisko klaušu jomā izmaiņas nebija tik būtiskas.

Nolikumu saturs ne vienmēr atbilda vēlākā laika dzīves prasībām. To centās novērst ar rātes un tiesu instanču instruktīviem norādījumiem, kurus norakstu veidā fiksēja amatu grāmatās. Atšķirībā no statūtiem, kurus amatiem bija svarīgi saglabāt un kuri tādēl pieejami arī mūsdienās, amatu grāmatas saglabājušās fragmentāri, jo to sastādīšanas laikā nebija nekādu nosacījumu vecāku periodu grāmatu glabāšanai. Liela dạ̧a amatu grāmatu, tāpat kā senākie amatu statūti, atrodami Rīgas senatnes pètītāju biedrības fondā (4038.).

Palīgamati darbojās amatu un ķemerejas tiesas uzraudzībā, tādēḷ raksta izstrādē izmantoti tās materiāli (1382. fonds), kā arī rātes (749., 673. fonds) un kases kolēgijas, t.i., pilsētas finanšu institūcijas (1390. fonds) dokumenti. Tās bija galvenās iestādes, kas kontrolēja sabiedrisko darbu uzdošanu, realizēšanu un izdevumu atlīdzināšanu. Tiesu un rātes sēžu protokolu grāmatās atrodami norādijjumi par praktisko sabiedrisko klaušu izpildi un amatu izteiktās iebildes vai komentāri. Šie materiāli papildina nolikumos atrodamos datus ar plašāku informāciju par veiktajiem darbiem, to biežumu, izpildi un citām niansēm.

Raksta izstrādes pamatu veido tiesu materiāli, ja konfliktos minētas sabiedriskās klaušas vai arī tās bijušas tiesāšanās iemesls. Kamēr neveidojās konflikti, kuri kaut kādā mērā skāra klaušu jautājumu, instances uzdeva amatiem darbus un tad sekoja darbu izpildei, nekādi neinterpretējot šo jautājumu.

Rīgas tiesu materiāli ir labi saglabājušies, īpaši tie, kuros tiesāšanās nonākusi līdz lemšanai Vidzemes (vēlāk Baltijas) generālgubernatora kancelejā vai Valdošajā Senātā. Prāvas dokumenti parasti ietver sūdzētāja vēstuli tiesai ar sūdzības pamatojumu, apsūdzētā atbildes vēstuli, tiesas pieprasītos papildus materiālus no citām 
iestādēm, ja tiesa tādus uzskatījusi par vajadzīgiem, abu iesaistīto pušu gala atbildes un tiesas lēmumu. Ja lēmumu kāda no pusēm virzīja uz apelāciju, tad puses atkārtoti rakstīja sūdzības un atbildes vēstules. Sabiedrisko klaušu regulāra pieminēšana konfliktsituācijās starp pilsētu, birgériem un amatiem l̦auj izkristalizēt strīdos iesaistīto pušu attieksmi pret tām un atklāt guberṇas vadỉbas un reizēm valsts valdības nostāju attiecīgajā jautājumā.

Orig̣inālu vai kopiju veidā tiesu dokumenti glabājas jau minētajos Rīgas rātes un tiesu fondos, arī Lielās un Mazās gildes (223. un 224.) materiālos, kur par atsevišḳām problēmām vai prāvām komplektēts visu saistīto dokumentu kopums no dažādām iestādēm.

Atšķirībā no nolikumu vai tiesu protokolu ierakstiem, kas ir īsi, konkrēti un uz tā brīža situāciju orientēti, prāvu dokumentos parādās plašāki pamatojumi ar strīdā iesaistìto pušu viedokli, arī nostāja pret sabiedriskajām klaušām un to izpildītājiem. Rakstītājs varēja izvēlēties sniegt plašāku ieskatu vēsturiski izveidojušos apstākḷlos vai klaušu izpildes norisē. Tā ir oficiāli pausta un juristu uzraudzībā tapusi nostāja, tādēl var neatspoguḷot visas birǵeru vai nevācu kopienas viedokli. Tomēr iesaistīto pušu dokumenti tapa, lai aizstāvētu tiesības vai vērstu uzmanību uz nelikumībām vai pāridarījumiem, tādẹl tekstos ietvertās tēmas tur negadījās nejauši un lietotie argumenti bija rūpīgi apsvērti.

Nav saglabājusies un arhīvos nonākusi privātā sarakste starp nevācu amatu locekḷiem, jo attiecīgajā laika posmā neeksistēja institūcijas, kas to varētu uzglabāt un vēlāk nodot arhīvos vai citās atmiņas institūcijās. LNA-LVVA 4011. fondā, kur glabājas dažādi materiāli par personām, nevācu amatu ǵimeṇu, piemēram, Nariṇu, Sẹlu, vecākie saglabātie dokumenti attiecas uz 19. gs. otro pusi un pārsvarā ir oficiāli paziṇojumi vai lietišḳā sarakste.

Latvijas historiogrāfijā, atšķirībā no zemnieku veiktajām klaušām, par pilsētas iedzīvotāju sabiedriskajiem pienākumiem rakstīts praktiski nav, izņemot, kad ir minētas šķūtis vai kādi konkrēti darbi. Tā kā sabiedrisko klaušu jautājums pieminēts ar mastu šḳirotāja Daniela Šteinhauera (1721-1761) darbību saistītajās prāvās, tad tas minēts starpkaru vēsturnieka Jāṇa Strauberga grāmatā. ${ }^{10}$ Autors nav sīkāk skaidrojis šo jautājumu, jo viņa galvenais pētījuma akcents bija likts uz savstarpējā konflikta izcelšanu starp "latviešu” un "vācu” kopienām, kas atbilda starpkaru perioda Latvijas 
jauno laiku vēstures interpretācijas koncepcijai. No padomju laika autoriem izcel̦ama tikai Meta Taube, jo viṇa savā pētījumā tirdzniecības palīgamatu veiktajiem sabiedriskajiem darbiem veltījusi atsevišķu nodalıu. ${ }^{11}$ Citi autori, kas rakstījuši par palīgamatiem, to veiktos sabiedriskos dienestus parasti nepiemin, bet apraksta amatu pamatdarbu ar precēm. ${ }^{12}$ Lai gan atbilstoši padomju laika prasībām Meta Taube, Melita Svarāne, Ilga Grasmane un Velta Pāvulāne piemin šķiru cīṇas jautājumu, tomēr viṇu pētījumi balstās pamatīgās Rīgas pilsētas vēstures avotu studijās. Viṇu galvenais mērḳis bijis izpētīt amatu darbỉbas nozìmi tirdzniecības preču apstrādē un parādìt to funkcionēšanas pamatprincipus. Sabiedriskās klaušas palikušas ārpus pētniecības pamatlauka, jo lielā mērā bija pilsētas iekšējās dzīves sfēra un minimāli skāra tirdzniecības un ekonomikas jautājumus.

Latvijas historiogrāfijā nepastāv vienota model̦a, kā tulkot pilsētā veiktos sabiedriskos pienākumus. Birǵeru sabiedriskos pienākumus avotos mēdz saukt par onera publica ordinaria und extraordinaria, citur onera civica. Aprakstot nevācu amatu darbus, kā būs redzams tālākā tekstā, bieži izmantots apzīmējums onera servilia. Vācu 19. gs. vārdnīcā onera servilia tulkots kā "Dienstlast". ${ }^{13}$ Citur tie paši darbi vienkārši apzīmēti kā onera vai publique Leistungen.

Jānis Straubergs onera servilia tulko kā "vergu darbi". ${ }^{14}$ Toties vēsturniece Meta Taube amatiem uzliktos pilsētas darbus dēvē par klaušām, bet oneribus servilibus pārtulko kā kalpības nastas. ${ }^{15}$ Abas versijas piešḳir nosaukumam noteiktu kontekstuālu nokrāsu, tādēḷ rakstā izmantots apzīmējums "sabiedriskās klaušas". Vietās, kur dokumentos plašāk apskatīti šie darbi, iekavās norādīts dokumentos lietotais origināls.

\section{SABIEDRISKĀS KLAUŠAS}

Baltijas guberṇās sabiedrības lielāko dạıu veidoja dzimtzemnieki. Viṇu veiktās klaušas muižā bija saistības pret muižnieku, kurš tās saṇēma no zemnieka kā atlīdzību par tiesībām apstrādāt noteiktu zemes gabalu un baudīt tā augḷus. Daḷai klaušu bija sabiedrisks raksturs, jo zemnieki remontēja cel̦us, tiltus, raka novadgrāvjus un veica citus tamlīdzīgus darbus kopienas labā. 
Pilsētas kopienā attieksmei pret darbu bija vēsturiski atšḳirīgs konteksts nekā uz laukiem. Pilsētās labklājības iegūšana bija gandrīz pilnībā saistīta ar gimenes profesionālo darbību, tādēḷ ātri izveidojās un nostiprinājās katras profesijas novērtējums atkarībā no iespējām ar šo nodarbošanos iegūt iztikas līdzekḷus. Līdz ar to arī pilsētu sabiedrībā profesija bija statusa simbols. ${ }^{16}$ Un ar to, kādam slānim piederēja cilvēks, bija cieši saistīta visu pārējo uztvere par to, kas šim cilvēkam varēja piederēt un kā viṇam bija jāuzvedas ikdienā. ${ }^{17}$

Pilsētā visiem iedzīvotājiem (izṇemot nelielu procentu pilsētā dzīvojošu dzimtzemnieku) bija brīva cilvēka statuss un viṇu veiktās sabiedriskās klaušas bija ieguldījums sabiedrības labklājībā un drošībā. Noteikti dienesti kopš viduslaikiem tika uzskatīti par vācu pilsētas iedzīvotāju kopīgo pienākumu - pilsētas aizsardzība kara apstākḷ̆os un sardzes dienests.

Karadarbība, ugunsgrēki un plūdi bija kopēja nelaime, tādēḷ arī prasīja kopīgu un saskaņotu rīcību, jo nebija izveidojušies profesionāli dienesti, kas ar to nodarbotos. Daudzus pienākumus bagātākais sabiedrības slānis laika gaitā aizstāja ar naudas nodevām, uzticot pilsētas vadībai rūpes par kopējo labklājību un drošību. ${ }^{18}$ Ipaši šì tendence redzama militārajā jomā - jaunajos laikos pilsētas aizsardzība pakāpeniski pārgāja no iedzīvotāju kompetences pilnīgā valsts kontrolē.

Lai gan 18. gs. Rīga atradās Krievijas impērijas sastāvā, pilsēta lielā mērā saglabāja agrāko pārvaldes, tiesisko un sabiedrisko struktūru, kas bija organizēta pēc vācu pilsētu parauga. Dažādu pienākumu veikšana sabiedriskās kārtības un drošības uzturēšanai, piemēram, naktssardzes un ugunsgrēku dzēšana, nebija sveša arī 18. gs. Iekškrievijas pilsētu iedzīvotājiem. Krievijas historiogrāfijā tiek uzskatīts, ka regulārie un nereglamentētie pienākumi, ko pilsētas iedzīvotājiem pēc vajadzības uzlika valsts, ieskaitot šķūtis, apgrūtināja pilsētas kopienu tiktāl, ka nẹ̦āva tai saimnieciski attīstīties un nostiprināt labklājību. ${ }^{19}$ Iekškrievijā no 18. gs. 70. gadiem atsevišķi nolikumi l̦āva sabiedrisko klaušu izpildē sūtīt trešo personu vai aizstāt klaušas ar naudas nodevu, bet sākotnēji tā uzskatīta par privilēgiju, nevis ikdienas praksi. ${ }^{20}$ Šeit saskatāma būtiska atškîrība no Rietumeiropas pilsētām, kā Kopenhāgena, Londona vai Parīze, kur naktssardzes un ugunsdzēšanas pienākumus jau 17. gs. veica pilsētas apmaksāti brīvprātīgie vai policijas darbinieki. ${ }^{21}$ 


\section{NEVĀCU AMATU VEIKTĀS SABIEDRISKĀS KLAUŠAS}

Kā iepriekš minēts, daudzi nevācu amatu noteikumi, kas funkcionēja arī 18. gs., bija pieņemti agrāk. Tajos reti pieminētas sabiedriskās klaušas. Vecākajās nevācu amatu 15. un 16. gs. šrāgās parasti bija norādīts, ka amata locekḷiem jāierodas noteiktās vietās karadarbības, ugunsgrēka, plūdu vai citu nelaimju gadījumos, ņemot līdzi atbilstošu aprīkojumu. Bija paredzēti arī sodi par neierašanos. ${ }^{22}$ Zvejnieku amata noteikumos darbi sabiedrības labā nav minēti. ${ }^{23} 18$. gs. un 19. gs. sākumā lietotos loču amata noteikumos minēts tikai tas, ka ločiem bez atlīdzības jāpiedalās boju izvietošanā un novākšanā. ${ }^{24}$ Ormaṇu amatam 17. gs. bija jāizved atkritumi no pilsētas, un viṇus nozīmēja materiālu pievešanai dambju būvei, lai gan amata statūtos nekas par to nebija minēts. ${ }^{25}$

18. gs. nolikumi nav daudz izsmel̦ošāki. 1740. gada liǵeru statūtos norādìts, ka pēc rātes pavēles amatam jāveic sabiedriskie darbi (publique Arbeiten) un ka visiem amata biedriem jāpiedalās ugunsgrēku dzēšanā. ${ }^{26}$ 1776. gada mastu šķirotāju nolikumā teikts, ka amatam labprāt jāpiedalās bez atlīdzības sabiedriskajos darbos, t.i., plostu tilta noṇemšanā un uzlikšanā, ceḷu remontos, ledus izciršanā Daugavā un citos darbos. ${ }^{27}$

Tikai 18. gs. otrās puses pārcēlāju statūtos sabiedriskie pienākumi (onera) aprakstīti salīdzinoši plaši. Norādīts, ka pārcēlāji gūst labumu un priekšrocíbas no viņiem iedalītajiem darbiem tirdzniecībā, tādēḷ viṇiem jādod laivas un cilvēki dažādām valsts un pilsētas vajadzībām. Dažreiz par darbiem bija paredzēta atlīdzība. Amatam pavasarī pirms tilta ielikšanas un rudenī pēc tā izṇemšanas bija jāatvēl satiksmes nodrošināšanai 10 laivas, t.s. "pulku laivas”, abos Daugavas krastos. Ja nepieciešams, bija jādod vēl vairāk laivu kara munīcijas, ekipāžu, kurjeru, steidzamu sūtījumu vai virsnieku pārvadājumiem. Pārējos cilvēkus pāri Daugavai bija jāceḷ par pilsētas noteiktiem izcenojumiem. Noteikumi ietvēra arī Daugavas uzraudzỉbas jautājumus pavasaros un rudeņos, kad upe nebija droši šķērsojama pa tiltu vai ledu. Diennakts režīmā vienam pārcēlājam ar diviem kārtīgiem kalpiem nepārtraukti bija jādežurē pilsētas vadības ierādītā vietā pie upes. 
Pārcēlāju pienākumos ietilpa arī plostu tilta likšanas un noṇemšanas darbi. Pavasarī bija jānogādā tilta sastāvdaḷas līdz pilsētai un rudenī tās jānovieto Sarkandaugavā. Par šo darbu pārcēlājiem pienācās atlīdzība no pilsētas kases. Bija jāpiedalās jūras un upes boju un līdzīgu norāžu izvietošanā un izņemšanā. Par cilvēku sūtǐšanu ledus ciršanai Daugavā, lai atvieglotu ledus iziešanu pavasaros, pārcēlājiem pienācās atlīdzība no pilsētas kases. No visiem šiem darbiem bija atbrīvoti amatā jaunuzṇemtie pārcēlāji pirmajā gadā, bet otrajā gadā viṇiem pirmajiem bija jābūt tajos iesaistītiem. ${ }^{28}$ 1798. gada statūtu jauninājums - visi transporta līdzekḷi, kas reg̣istrēti pārcēlāju amatā, ieskaitot tos, kas nepiederēja pārcēlājiem, pildīja minētos darbus, cik to aț̣āva kravnesība. Ja kāds nevarēja vai negribēja izpildìt savu dạ̣u darbu, tam bija jāsarunā kāds cits savā vietā. ${ }^{29}$

Tā kā daudzos statūtos sabiedriskās klaušas nav aprakstītas vai ir tikai pieminētas, tad nolikumi dod visai maz informācijas par amatu veiktajiem darbiem. Tāpēc jāizmanto tiesu materiāli, lai uzzinātu sabiedrisko klaušu faktisko norisi. Var izdalīt ārkārtas un regulārās klaušas.

No ārkārtas gadījumiem var minēt piemēru, kad 1721. gadā sprāga pulvertornis pie Miesnieku vārtiem (pie pils), aprokot zem drupām cilvēkus. Lai pēc iespējas ātrāk atrastu un aizvāktu lỉkus, birğeri bija devuši naudas līdzekḷus, bet vietējo kurpnieku, drēbnieku, audēju, kalēju un ormaņu amatam uzdeva piedalīties praktiskajos darbos. Bez tam amati ziedoja naudas līdzekḷus pilsētas kasē. ${ }^{30}$ Savukārt 1805. gadā zvejniekiem dots rīkojums palīdzēt strūgām, kas seklā ūdens dēl nevar turpināt ceḷu, bet par to bija paredzēta atlīdzība. ${ }^{31}$

18. gs. sāls nesēju, lig̣eru un kaṇepāju kulstītāju klaušas (onere) ietvēra šādus darbus:

1) boju izvietošana Daugavā un jūrā;

2) plostu tilta ielikšana un izņemšana;

3) bastionu un tur izvietoto lielgabalu tīrīšana;

4) dambju, pilsētas vārtu un tiltu uzraudzība ledus iešanas laikā (kamēr ledus izgāja, 12-20 cilvēkiem bija jāatrodas sardzē pie vārtiem, bet pēc tam jānovāc no tirgus laukuma un krasta nocietinājumiem pāri palikušais ledus); 
5) piedalīšanās naktssardzē (kopā ar vīna nesējiem - no amatiem izvēlēja 16 cilvēkus, kuri pa astoṇiem pārmaiņus katru otro nakti patrulēja pilsētā ar klabekḷiem rokās; Jāṇu svētku laikā bija jāpiesaista vēl vairāk cilvēku, lai cīnītos pret zādzībām, kad cilvēku nav mājās);

6) imperatora Pētera I nama (tag. Palasta ielā) uzkopšana;

7) uz vaḷniem izvietotā šaujampulvera uzraudzība;

8) Daugavas krasta uzkopšana pie iekšpilsētas;

9) Jāṇa dambja (Maskavas priekšpilsētā) papildināšana ar smiltīm un būvgružiem, visu dambju uzraudzība;

10) artilērijas izvietošana uz valıniem;

11) piedalī̌̌anās glābšanas darbos uguns un ūdens nelaimju gadījumos, degušās vietas apsargāšana pēc ugunsgrēka nodzēšanas. ${ }^{32}$

1738. gadā rāte nolēma uzticēt boju izvietošanu un izņemšanu loču amatam, atbrīvojot no šì pienākuma sāls nesējus, ligerus un kaņepāju kulstītājus. Ločiem darbu veikšanai bija nolemts piešḳirt divas laivas un piekomandēt namdari, kalēja mācekli un minsterejas tiesas darbinieku. Par darbu veikšanu bija paredzēta neliela atlīdzība. Izrādījās, ka pavasarī ločiem ir daudz darba ar ienākošajiem kuğiem. Rāte tomēr uzskatīja, ka arī tirdzniecības palīgamati pavasarī ir noslogoti un boju izvietošanai nepieciešamie strādnieki jāpieṇem ločiem par saviem līdzekḷiem. Rāte šo lēmumu argumentēja ar to, ka loči no citiem oneribus publicis ir atbrīvoti. ${ }^{33}$ Sāls nesēju grāmatā atrodama piezīme, ka sāls nesēji bijuši l̦oti pateicīgi amata vadībai par centieniem atbrīvoties no apgrūtinošā boju izvietošanas pienākuma. ${ }^{34}$

Vīna nesēju amata pienākumi bija:

1) pāḷu izvietošana Daugavas krastu aizsardzībai no ledus no pilsētas līdz Doles salai;

2) plostu tilta izciršana no ledus - gadijumos, kad tas nav laikā izṇemts un iesalis, strādājošie saṇēmuši no pilsētas alus porcijas. ${ }^{35}$

Par 18. gs. pirmo pusi pieejamā informācija vairāk atspoguḷo dažādu nesēju amatu veiktās sabiedriskās klaušas, kamēr par 18. gs. otro pusi atrodamie dati vairāk skar amatus, kuru darbība saistīta ar Daugavu. 
Pārcēlāju, zvejnieku, enkurnieku un mastu šḳirotāju amats piedalījies plostu tilta izṇemšanā, ielikšanā un nogādāšanā uz ziemošanu Sarkandaugavā. Par to saṇemta atlīdzība no pilsētas. ${ }^{36}$ Plostu tiltu dažādos gados bija iespējams ielikt stipri atškirīgos laikos, atkarībā no laikapstākḷiem. Var secināt, ka arī citi ar to saistītie darbi - Daugavas vai dambju uzraudzība atkarībā no sezonas varēja būt ilgstošāka un sarežgìitāka vai otrādi. Tilta atgādāšana un ielikšana aizṇēma vairākas nedēlas.

Mastu šķirotāju komentāros pie 1776. gada statūtiem redzams, ka viņi lūdza pilsētas vadību pilnībā atbrīvot amatu no sabiedriskajām klaušām (publique Arbeiten). Iepriekš tās veiktas "no brīvas gribas", bet amats vairs nevēlējās ciest tādus apgrūtinājumus, jo tam jāsamierinās ar daudzu karavīru izvietošanu mājās, savukārt uzturu viṇi pelnot lielākoties Polijā. ${ }^{37}$

\section{SABIEDRISKĀS KLAUŠAS KĀ ARGUMENTS TIESU PROCESOS}

18. gs. un 19. gs. sākuma tiesu procesos starp nevācu amatiem un pilsētu vai birǵeriem ir atrodamas prāvas, kurās kā arguments savas nostājas pamatošanai izmantots sabiedrisko klaušu jautājums, lai gan pamata strīda objekts ir bijis cits. 18. gs. norisinājušies trīs tāda tipa konflikti. Šeit ieskicēti tikai to pamatelementi, lai būtu skaidrs, kādēl sabiedrisko klaušu jautājums prāvās tika aktualizēts.

Pirmais konflikts starp birgeriem un nebirgeriem, kur atrodams sabiedrisko klaušu jautājums, ir no 1738. līdz 1740. gadam ilgušais strīds par īpašumtiesībām. Tas plaši analizēts Jāṇa Strauberga grāmatā. ${ }^{38}$ Tirgotāju un amatnieku kopiena uzskatīja, ka iegūt zemes gabalus dzimtīpašumā (erb und eigentümlich) pilsētā vai priekšpilsētās var tikai birǵeri. Viṇi lūdza rāti pavēlēt nebirǵeriem pārdot šāda tipa īpašumus un noliegt turpmāk tādus iegādāties. Kad rāte tā arī rìkojās, tai sūdzējās "vietējie brīvie iedzīvotāji”, kuri vēlāk sevi identificēja kā ormaṇu, zvejnieku, pārcēlāju un mastu šḳirotāju amati. Vidzemes ǵenerālgubernators Pēteris Lasī (Lacy, 1677-1751) konfliktu izsprieda par labu nevācu amatiem.

Nākamais konflikts, kurā par argumentu kalpojušas arī sabiedriskās klaušas, bija mastu šķirotāja Daniela Šteinhauera strīds ar 
pilsētu birǵeru tiesību piešḳiršanas jautājumā 18. gs. vidū. To izsprieda Valdošajā Senātā par sliktu Šteinhaueram.

No 1750. līdz 1753. gadam norisa strīds starp birgeriem un nevācu amatiem par krogēēsanas tiesībām. G̦ildes krogu un iebraucamo sētu turēšanu uzskatīja par birgeru pārtikai piederīgu, tātad citiem pilsētas iedzīvotājiem aizliegtu. Sāls nesēju, liğeru un kaņepāju kulstītāju amats aizstāvēja tiesības pārdot alu līdzīgi citiem pilsētas amatiem un atsaucās uz zviedru laiku pilsētas nolikumu. Vidzemes ǵenerālgubernatora p.i. valdības padomnieks Johans Baltazars Kampenhauzens (Campenhausen, 1689-1758) lēma par labu amatiem. Birğeri lēmumu pārsūdzēja justīckolēgijā, un tā atbalstīja birgerus, jo uzskatīja, ka dokumentāli pierādīts fakts - Rīgā tikai birgeri drīkst turēt krogus un pārdot alu. ${ }^{39}$

18. un 19. gs. mijā vēl divos konfliktos ieskanējās sabiedrisko klaušu jautājums. Zvejnieks Sīmanis Raņķis (1743-1814) prasīja pilsētai birgeru tiesības zvejnieku un pārcēlāju amata locekḷiem. Lieta izspriesta Valdošajā Senātā par sliktu amatiem.

Lìdzīgs gadījums ir 19. gs. sākuma pilsētas un pārcēlāju amata konflikts sakarā ar 1798. gadā ieviesto pārcēlāju reglamentu. 1804. gadā pārcēlāju eltermanis Tomass Sēlis (1763-1830) sūdzējās par rindas kārtības ieviešanu pārcēlāju darba izpildē. Lieta izskatīta Vidzemes gubern,as valdē un nolemts reglamentu nemainìt.

Visos piecos minētajos konfliktos, formulējot pilsētas vai birgeru viedokli par konkrēto situāciju, apskatīts sabiedrisko klaušu jautājums. Kopumā tas formulējams šādi:

1) nevācu amatu locekḷi nevarēja piederēt pie birǵeru kopienas vai vācu amatnieku cunftēm un nevarēja "nest" birgeru nastas (bürgerliche onera), jo viņu priekšteči bija dzimtzemnieki, kuri no kaimiṇu provincēm bēguši uz Rīgu un kḷuvuši par dienas algādžiem un strādniekiem;

2) nevācu amatu locekḷi netika uzskatīti par dzimtcilvēkiem, bet arī par pilnīgi brīviem cilvēkiem viņus atzīt nevarēja;

3) amatos viṇi bija apvienoti tikai tādēḷ, lai būtu vieglāk kontrolējami;

4) lai viņi neaizmirstu savu izcelšanos un netiektos pēc birğeru labumiem, bet vienmēr atcerētos savu izcelšanos un nebrīvo kalpu stāvokli (Knechtschaft, krievu tekstā - rabstvo ${ }^{40}$ ), tiem uzlikti specifiski darbi (servilische Verrichtungen, knechtliche 
Dienstleistungen ${ }^{41}$ ) jeb kalpu nastas (onera servilia), kas jāveic bez atlīdzības un kādus nekad neuzliktu pilnīgi brīviem cilvēkiem; ${ }^{42}$

5) par kūtrību darbu veikšanā nevācu amatu locekḷus varēja sodit ar miesas sodiem. ${ }^{43}$

Atbildot uz minētajiem apgalvojumiem, nevācu amati parasti akcentēja veikto pienākumu nozīmi pilsētas aizsardzībā un kārtības uzturēšanā. Viṇu pausto nostāju var apkopot šādi:

1) amati vienmēr pildījuši pienākumus (Pflichte und Schuldigkeit, publiqen Arbeiten) un par noteiktiem darbiem no pilsētas solìta un saņemta atlīdzība;

2) veiktos darbus nevar uzskatīt par apkaunojošiem vai kalpu nodarbēm jeb onera servilia;

3) arī birǵeri pilda pienākumus pret valsti un pilsētu;

4) dalıu no pienākumiem amati veic, algojot kalpus, un tas apliecina viṇu mīlestību pret pilsētu. Tāpat Šteinhauers aizrādija, ka apkaunojošs darbs nav izvietot lielgabalus uz vaḷņiem, jo to darot arī karavīri, bet no tiem Rìgas birgeri nekaunas un nenovēršas. ${ }^{44}$

Tikai Tomasa Sēḷa komentāros ieskanas nedaudz cits akcents, jo viņš noraidīja sabiedrisko klaušu veikšanu kā tādu. Sēlis uzskatīja, ka brīvus cilvēkus nevar pataisìt par vergiem, uzliekot godu nedarošu darbu veikšanu par velti. ${ }^{45}$ Tos var uzdot sodītām personām. Ja darbu piešķiršana notiek, n̦emot vērā tikai amata locekḷu izcelšanos, kā to pamatojot rāte, tad tas notiek "uz tautas rēkina”. Kas tā būtu par tautu, kas būtu dzimusi, lai veiktu apkaunojošus darbus? No šĩs tautas (nevācu amatu gimeṇu locekḷu - A. Č.) vidus nākuši virsnieki, profesori un ierēdņi, citi sasnieguši pārticību ar tirgošanos, kas pierāda, ka šie l̦audis nav dzimuši, lai tīrītu ielas. ${ }^{46}$

Visai reti valdošo instanču lēmumos ieskanējies arī sabiedrisko klaušu jautājums. Tas atrodams divos dokumentos. 1752. gada Senāta lēmumā par sliktu Šteinhaueram minēts, ka viṇš nav varējis skaidri norādīt, no kurienes cēlušies un kādai nācijai piederējuši viņa senči, un ka rāte precīzi definējusi atšḳirību starp vāciešiem un nevāciem, kuri izslēgti no birǵeru tiesībām un nozīmēti kalpu darbos. ${ }^{47}$

1753. gada janvārī Vidzemes generālgubernatora p.i. Kampenhauzens krogeéěanas strīdā norādīja, ka nevācu amati uzskatāmi par 
pilsētas iedzīvotāju kopai piederošu daḷu. Sabiedriskās klaušas (Praestationes) viņi veic nevis konkrētu cilvēku, bet visas sabiedrības labā. Esot aizspriedumaini tos uzdot par onera servilia, it īpaši tādēl, ka kara laikos birǵeriem arī ir jāpilda onera. Iepazīstoties ar abu pušu argumentiem, Kampenhauzens bija nonācis pie secinājuma, ka nevācu amatus jāuzskata par brīvām cunftēm ar savām specifiskām tiesībām, ieskaitot krogēēanu. ${ }^{48}$

\section{SABIEDRISKĀS KLAUŠAS KĀ STRĪDU OBJEKTS}

19. gs. sākumā atrodamas vairākas strīdu situācijas, kurām iemesls bijušas sabiedriskās klaušas - to izpildes kārtība vai atlīdzības jautājumi. Iezīmīgi, ka šie strīdi parādās pēc tam, kad pilsēta tos izmantojusi kā būtisku argumentu nevācu amatu statusa interpretēšanai. Šeit dokumentu komplekss par katru prāvu skatīts atsevišḳi, lai būtu redzams plašākais sūdzības konteksts un tā risinājums.

1801. gadā lig̣eri, kaṇepāju kulstītāji, sāls un labības mērītāji sūdzējās rātei par kases kolēgiju, kas atteikusies apmaksāt amatu iesniegto rēķinu par strādnieku atalgojumu. Strādnieki bija pieņemti, lai ledus iešanas laikā slēgtu un bloḳētu pilsētas vārtus Daugavas pusē. Agrāk to bija uzticēts darìt garnizona karavīriem virsnieku un kavartālu uzraugu vadībā. Zaldāti radījuši pietiekami daudz nekārtību, lai 18. gs. 80. gados ķemerejas tiesa rosinātu un rāte piekristu šo pienākumu nodot palīgamatiem. Tiem uzdots bloķēt vārtus, pēc ledus iešanas tos attīrìt un aizvākt atkritumus. Par darbu solìta neliela un tobrīd nenoteikta atlīdzība. Katru gadu amati iesniedza kases kolēgijā rēḳinu par strādnieku piesaistīšanu šiem darbiem un tas tika apmaksāts. ${ }^{49}$ Viṇi bija gatavi veikt visus darbus un dienestus, kas tiek uzlikti viņiem kā padotajiem un attiecas uz visiem pilsētas iedzīvotājiem. Amati uzskatīja, ka no viṇiem kā brīviem cilvēkiem, kroṇa nodevu maksātājiem, nevar prasīt veikt onera servilia. Amatu instrukcijas neliecina, ka vinus var piespiest strādāt par velti. Amati prasīja atlīdzību par strādnieku uzraudzī̌anu, jo klaušu izpilde lika uzturēties ārpus mājas, kas savukārt radīja vairāk izdevumu nekā būšana mājās. ${ }^{50}$ 
Kases kolēgija bija gatava apmaksāt rēḳinu, bet lūdza turpmāk fiksēt strādnieku atlīdzību un amatu iesniegto rēķinu katru gadu apstiprināt policijā. Kolēg̣ija uzskatīja, ka amatiem par strādnieku uzraudzību nav jāmaksā, jo darbs ietilpst amatu sabiedriskajās klaušās (öffentliche Verpflichtung). ${ }^{51}$ Tas, ka amatu locekḷi maksā kroṇa nodevas, neatbrīvojot viṇus no darbiem pilsētas labā, un viṇu brīvība nav nekādi aizskarta. ${ }^{52}$

Amati norādīja, ka strādnieku atalgojums mainās pa gadiem, pat pa mēnešiem, atkarībā no strādnieku pieejamības pilsētā un citiem apstākḷiem. ${ }^{53}$ Fogtejas tiesa, kas Rīgā izskatīja civilās prasības pilsētas teritorijas ietvaros, sniedza atzinumu, ka amatu iesniegtais rēķins būtu jāapmaksā, tas jādara arī turpmāk, fiksēta alga strādniekiem nav nosakāma, rēḳinu policijā apstiprināt vajadzētu, bet pašiem amatu locekḷiem par strādnieku uzraudzību jāmaksā nebūtu. ${ }^{54}$

Amati ar šādu lēmumu nebija mierā un to pārsūdzēja rātē, kas atstāja fogtejas lēmumu nemainītu, atsaucoties uz tām pašām instrukcijām, kas uzliek amatiem veikt oneribus servilibus jeb darbus par velti un kuras katrs amatā pieņemtais loceklis apzvēr pildīt un dara to labprātīgi. Rāte izskaidroja, ka onera servilia nav darbi, kas uzdoti dzimtl̦audim, bet gan darbi, par kuriem nevar prasìt un nevar noteikt atlīdzību. Kurš negrib pildìt šādus darbus, var izstāties no amata. ${ }^{55}$

Šajā pašā laikā minētie amati (lig̉eri, kaṇepāju kulstītāji, sāls un labības mērītāji) kopā ar vīna nesējiem par pilsētas vadības attieksmi pret tiem sūdzējās speciāli izveidotai komitejai, kas kopš 1802. gada izvērtēja pilsētas nolikumu un privilēgijas. Šādas komitejas tolaik tika veidotas visās lielākajās Krievijas pilsētās ar mērḳi noskaidrot reālo stāvokli tiesiskajā un finanšu jomā. ${ }^{56}$ Amati norādỉja, ka tie ir seni pilsētas formējumi, kuros bijuši iesaistīti seno lỉbiešu pēcteči un kuriem pilsētas vadība uzlikusi apgrūtinošus pienākumus (onera personalia), kam nav nekāda sakara ar amata tiešajiem pienākumiem un kas ir pretēji veselajam saprātam un taisnīgumam. Kā piemēru amati minēja naktssargu sūtīšanu, ko uzskatīja par negodīgu, jo viņi jau maksāja ugunsdzēšanas un naktssargu nodokli. Amati norādīja, ka kopš 1799. gada 1. decembra viṇi kā visi citi iedzīvotāji ir iekḷauti nodokḷu maksātāju grupās, bet neviens nav atcēlis šos daudzos pienākumus un par to veikšanu 
viṇi nesaṇem atlīdzību. ${ }^{57}$ Pilsēta, atbildot uz amatu sūdzību, norādīja, ka ne vienmēr uzskaitītie darbi veikti par velti. ${ }^{58}$

Kopumā minēto komiteju darbībai nebija īpašas sekas Krievijas pilsētu dzīvē, ja neskaita Maskavā un Pēterburgā atceltos sardzes dienestus un vēl dažas maznozīmīgas izmaiņas. Šajā kontekstā var minēt vēsturnieka Manfreda Hildermeijera secinājumu, ka pienākumu veikšanas aizstāšana ar fiskālo slogu tikai mainīja pilsētnieku apgrūtinājumu veidu, nevis atviegloja dzīvi. ${ }^{59}$

Lìdzīga satura sūdzību 1809. gadā sniedza mastu šķirotāju amats. 1808. gada martā Vidzemes gubernators Kristofs Adams fon Rihters (Richter, 1751-1815) bija uzdevis rātei izcirst ledu ap Daugavas salām, ar norādi, lai šos darbus veic vietējie amati. Rāte to uzdeva pārcēlājiem, zvejniekiem, enkurniekiem, mastu un ozolkoku šķirotājiem. Viṇiem piešķīra strādniekus - 110 vietējos iedzīvotājus ar vajadzīgo aprīkojumu. Amats to uzskatīja par darbu sabiedrības labā, kas būtu jāapmaksā no pilsētas līdzekḷiem vai jāuzliek visiem iedzīvotājiem. Pilsētas vadība norādīja, ka par darbu uzlikšanu sūdzējies arī ozolkoku šķirotāju amats un ka nevienam no tiem nav tiesības prasīt atlīdzību. ${ }^{60}$ Savukārt guberņas valde atbildēja, ka saskaṇā ar amata noteikumiem tiem ir jāveic noteikti darbi sabiedrības labā, ieskaitot ledus ciršanu Daugavā. ${ }^{61}$ Tomēr tālāk atzina, ka agrāk, pirms simts un vairāk gadiem, kad nebija dažādu likumu par guberņām, pilsētas un tirdzniecības nolikuma, tad rāte varēja rīkoties pēc saviem ieskatiem un uzlikt bez atlīdzìbas darbus tā laika koku šḳirotājiem, neskatoties uz to, ka viņi bija brīvi cilvēki. Agrāk valdījusi tāda nostāja, ka, ja amatiem tiek labums no sabiedrības, tad arī tiem ir jāstrādā sabiedrības labā. Šobrīd likumi nosaka, ka bez imperatora ziṇas jaunus nodokḷus, norīkojumus un nodevas uzlikt nedrīkst. ${ }^{62}$ Tomēr valde neuzskatīja, ka ir uzlikusi kādam jaunu nastu, un piemetināja, ka citi amati nesūdzas. ${ }^{63}$ Pateicoties šādai pilsētas un guberṇas valdes nostājai, jautājums netika izlemts par labu amatiem.

Pretējs rezultāts atrodams citu amatu sūdzībai. 1808. gada rudenī ligeru, sāls un labības mērītāju, kaṇepāju kulstītāju un vīna nesēju amati iesniedza sūdzību fogtejas tiesai par kases kolēgijas nevēlēšanos apmaksāt amatiem 1807. un 1808. gadā radušos ar lielgabalu pārvietošanu saistītos izdevumus, kā arī par ledus iešanas 
laikā veiktajiem darbiem. Izdevumos ietilpa gan pieņemtajiem strādniekiem izsniegtā atlīdzība, gan amatu "pụ̄̂lu" atlīdzināšana. ${ }^{64}$ Kases kolēgija uzskatija, ka amatu instrukcijas paredz oneribus servilibus personīgu un paklausīgu izpildi, nevis uz pilsētas rēḳina pieņemtu strādnieku uzraudzību. Vidzemes gubernators Rihters un rāte 1808. gadā noteikusi, ka ledus iešanas laikā amatiem vārtu bloķēšanai, naktssardzei un ūdens pumpēšanai vajadzīgie cilvēki jāsagādā uz sava rēķina. Tikai lielos plūdos pilsētai amati jāatbalsta ūdens pumpēšanas darbos. ${ }^{65}$ Vèlāk kases kolēgija tiesai iesniedza izrakstus no mērìtāju, liğeru, kaṇepāju sējēju (nevis kulstītāju, kas ir cits amats $-A$. $\check{C}$.) un vīna nesēju instrukcijām, kurās visās bija minēts, ka amatiem paklausīgi jāveic oneribus servilibus, bet nevienai no instrukcijām nebija norādīts izdošanas gads un izraksti bija praktiski vienādi, tikai ar nelielām lingvistiskām atšḳirībām. ${ }^{66}$ Amati atbildēja, ka neko nezina par kases kolēgijas minētajām instrukcijām un ka tikai Krievijas imperatoram ir tiesības uzlikt jaunus nodokḷus, nastas un darbus. ${ }^{67}$

Fogtejas tiesa šajā lietā lēma, ka kases kolẹgijai jāatmaksā strādniekiem dotā atlīdzība, bet nav jāatmaksā amatu pieprasîtās summas par strādnieku uzraudzī̌sanu ${ }^{68}$ Kases kolēgija nebija mierā ar lēmumu un pārsūdzēja to rātēe. ${ }^{69}$ Tā lietu izsprieda par labu kases kolègijai, jo uzskatīja, ka palīgamati par brīvìbu un ienesīgu amatu pilsētai ir parādā noteiktus dienestus. ${ }^{70}$

Amati lietu grasījās pārsūdzēt justīckolēgijā, bet tā visdrīzāk pārsūtīta izskatîšanai Senātā, kurš, pēc ziṇu ievākšanas par lietas apstākḷiem no Rìgas kara gubernatora Filipa Pauluči (Paulucci, 1779-1849), 1817. gadā pieņēma lēmumu par labu amatiem. ${ }^{71}$

Pauluči bija norādījis, ka pilsēta dažādu darbu uzdošanu amatiem pamato ar tiem dotajām ekskluzīvajām priekšrocībām darbos ar tirdzniecības precēm un ka amatu instrukcijas tiešām paredz kārtīgi pildīt tām uzliktos pienākumus (Dienstbarkeit). Tomēr no tā neizriet, ka amatiem jāveic visi pilsētas uzdotie darbi vai jāpieņem to veikšanai strādnieki. Pauluči likās pašsaprotami, ka uzliktos darbus nevar veikt tikai ar amata biedru spēkiem un ir jāpieņem papildus strādnieki. Pauluči norādīja, ka ne tikai amati, bet arī pati pilsēta pelna no tirdzniecības un ka darbu dēl amata locekḷiem jāpamet ğimenes tieši bīstamajā ledus iešanas laikā. ${ }^{72}$ Pēc iepazīšanās ar šo Pauluči viedokli Senāts atzina fogtejas tiesas lēmumu par 
pamatotu un uzdeva Vidzemes guberņas valdei vērot, lai kases kolēgija to izpildìtu. ${ }^{73}$

Pamatojoties uz šo lēmumu, amati prasīja atmaksāt strādnieku pieņemšanu vārtu bloḳēšanas darbiem no 1807. līdz 1818. gadam, lielgabalu pārvietošanas darbiem - no 1807. lìdz 1810. gadam, slūžu nostiprināšanas un ūdens atpumpēšanas darbiem - no 1808. līdz 1818. gadam un ledus aizvākšanai no krastmalas - par 1809., 1810. un 1814. gadu. ${ }^{74}$ Kases kolēgija tomēr sūdzējās fogtejas tiesai par atsevišķiem rēķinu punktiem, uzskatīja amatu datus par neuzticamiem un prasīja papildus pierādījumus, sevišķi par senāko periodu. ${ }^{75}$ Amati norādīja, ka apstiprināt vecākos rēḳinus vairs nav īsti kam, jo virsnieki garnizonā gadu gaitā bija nomainījušies. Vecākās amatu grāmatas vietas trūkuma dēl jau bija iznīcinātas. ${ }^{76}$ Kases kolēgija līdz ar to bija ar mieru apmaksāt tikai nelielu daļu no prasìtās summas. ${ }^{77}$ Šì raksta kontekstā gan nav tik svarīgi, cik naudas atguva amati pēc vairāk nekā 10 gadus ilgušas tiesāšanās, bet būtiski ir tas, kādus argumentus izmantoja visas iesaistītās puses, lai pamatotu savu viedokli konkrētā situācijā attiecībā uz sabiedrisko klaušu izpildi.

\section{SECINĀJUMI}

18. gs. pārmaiṇas sabiedriskajos un ekonomiskajos procesos nenoliedzami skāra Latvijas teritoriju, tajā skaitā arī attieksmē pret sabiedriskajām klaušām Rīgā, kur šādas klaušas bija ierasta jauno laiku parādība. Rīgā nepastāvēja skaidra sabiedrisko klaušu reglamentācija ne pilsētas izdotajos aktos, ne nevācu amatu organizācijas dokumentos. Vienīgais izṇēmums ir pārcēlāju reglaments, kurš izstrādāts tikai 18. gs. otrajā pusē, kur pilsētas centās skaidri definēt veicamos uzdevumus, laikus un izpildes kārtību.

Ārkārtas klaušas bija saistītas ar uguns, ūdens, kara un citām nelaimēm.

Regulārās sabiedriskās klaušas iedalāmas trijās lielās grupās:

1) ar Daugavu saistītās - plūdu, palu bīstamības novēršana, rūpes par tiltu, bojām, dambjiem un drošu upes šḳērsošanu;

2) ar drošību un kārtību pilsētā saistītās - tīrības uzturēšana, sardzes; 
3) ar militārajiem dienestiem saistītās - artilērijas, šaujampulvera un karavīru pārvadāšana.

Darbi nebija uzdoti visiem nevācu amatiem kopā, bet nodalīti divās grupās - ar Daugavu saistītie amati (koku šķirotāji, loči, zvejnieki un pārcēlāji) un preču pārvadātāji (ligeri, kaņepāju kulstītāji, dažādi nesēji). Arī sūdzībās vērojami šie nogrupējumi, bet nekad abas grupas nav uzstājušās kopā. Vismazāk ziṇu atrodams par zvejnieku un loču veiktajiem darbiem, kā arī par sūdzībām, kas nāktu no vinu puses.

No 18. gs. 30. gadu beigām aizsākušajos strīdos starp pilsētas vadību, birğeru kopienu un nevācu amatiem par dažādiem ekonomiskas un tiesiskas dabas jautājumiem (zemes īpašumi, krogu turēšana, birg̣eru tiesības) pilsētas vadība un birg̀eru organizācijas formulēja sabiedrisko klaušu uzlikšanu kā nevācu amatu locekḷu statusa noteikšanas argumentu, kā nepilnīgas brīvības raksturlielumu. Līdz ar to vismaz retorikā pilsētas vadỉba un birgeri vēl joprojām uzskatīja par pašsaprotamu, ka eksistēja ar labklājību, izcelšanos un profesiju saistītas tiesiskās atškịiribas starp dažādiem iedzìvotāju slāņiem. Īpaši svarīga iesaistīto pušu formulējumu noskaidrošana ir tādēl, ka 18. gs. iezìmīgs ar to, ka termini un to traktējums kḷūst par nozīmīgu argumentu politiskos strīdos, par pārliecināšanas līdzekli tikpat lielā mērā kā par realitātes apjēgšanas lìdzekli. ${ }^{78}$

Nevācu amatu locekḷi minētajos strīdos sabiedriskās klaušas interpretēja kā ieguldījumu pilsētas labklājībā un drošībā. Vēl viena iezīme, kas izsekojama viṇu nostājā, ir akcents uz atlīdzības saṇemšanu par darbiem, kā arī to, ka šos darbus veic ne tik daudz paši amatu locekl̦i, cik viņu algoti kalpi.

19. gs. sākumā strīdos, kas saistīti ar sabiedriskajām klaušām, redzama attieksmes maiṇa. Amati stingri uzstāja uz atlīdzības saņemšanu par sabiedriskajām klaušām un gadiem ilgi par to tiesājās. Formulējot savu nostāju, amatu locekḷi izvirzīja agrāk neizskanējušu viedokli par to, vai šādus darbus var uzlikt brīviem cilvēkiem un vai tas nav apkaunojoši un negodīgi. Kā alternatìvu amati redzēja šāda tipa darbu uzdošanu visiem iedzīvotājiem. Nav skaidri nosakāms, vai attieksmes maiņu radīja pilsētas vadības un birǵeru organizāciju pusgadsimtu ilgusī retoriskā prakse onera servilia jautājumā. Iespējams, 19. gs. sākuma nevācu amatu aktīvajiem 
locekḷiem bija izveidojusies savādāka attieksme pret pilsoni, darbu un samaksas jautājumu kopumā, nekā tas bija iepriekšējai paaudzei.

Šajās situācijās valdošajām institūcijām nebija vienotas pozīcijas sabiedrisko klaušu jautājumā. Iespējams, tas skaidrojams ar to, ka Iekškrievijas pilsētās iedzivotāju tiesiskajam statusam bija citi pamati un pienākumu pildīšana pret valsti un pilsētu bija iedzivotāju dzīves neatṇemama sastāvdaḷa. Gadījumos, kad nevācu amatu viedokli atbalstīja kāda augstāka amatpersona, viṇiem par labu varēja lemt arī augstākās varas instances, bet pārsvarā tas tā nenotika.

Pilsētai arī pēc strīdiem par sabiedrisko klaušu apmaksu izdevās šajā jautājumā saglabāt zināmu status quo. 19. gs. pirmās puses dokumenti liecina, ka tirdzniecības palīgamati turpināja pildìt uzliktos darbus, bet par atsevišķu pakalpojumu veikšanu valsts vai pilsētas labā saṇēma atlīdzību. ${ }^{79}$ Atrodamas arī liecības, ka daḷa darbu tā arī palika neapmaksāti. Vēl liǵeru 1855. gada lūgumā nesamazināt takses norādīts, ka amats dalı ienākumu tērē "kopējam labumam”, uzturot 10 naktssargus, piedaloties vārtu bloḳē̌̌anā ledus iešanas laikā un ugunsgrēku dzēšanā. ${ }^{80}$ Arī diskusijas par uzliekamajiem darbiem nekur nepazuda. Piemēram, 1840. gadā policijas priekšnieks Aleksandrs Jazikovs (Iazykov, 1802-1878) rakstīja rātei: "Tas ir uzkrītoši, ka zvejnieku amats, kuram ir bagātīgi ienākumi, no onera publica gandrīz pilnībā ir atbrīvots un sabiedriskajam labumam gandrīz neko nepienes." ${ }^{11}$

Respektīvi, sabiedrisko klaušu jautājums nepazuda no pilsētas dzīves, bet skaļu konfliktu trūkums liecina, ka pilsētas vadība un amati spēja atrast kompromisu un vienoties par darbu izpildi. Turklāt 19. gs. gaitā palīgamatu lomai attiecīgo darbu izpildē bija jākḷūst aizvien maznozīmīgākai, attīstoties policijas, ugunsdzēsības, komunālajiem un citiem dienestiem. Paralēli tam daḷai amatu pilsēta atcēla monopoltiesības uz viṇu nodarbēm, kā rezultātā amati pārstāja eksistēt. 


\section{ATSAUCES UN PIEZĪMES}

1 Anette Völker-Rasor (Hg.) (2000). Frühe Neuzeit. München: R. Oldenbourg Verlag, S. 45-48.

2 Lothar Gall (1995). Vom Stand zur Klasse? Zu Entstehung und Struktur der modernen Gesellschaft. Historische Zeitschrift, Bd. 261, H. 1, S. 1-21, šeit 5., 7. lpp.

3 Turpat, 8. lpp.; Leonhard Bauer (1984). Arbeit ist nicht gleich Arbeit: Die gesellschaftliche (erzwungene) Bewertung von Tätigkeiten. Jahrbuch für Sozialwissenschaft, Bd. 35, H. 1, S. 66-91, šeit 76. lpp.; Joachim Eibach (2009). Versprochene Gleichheit - verhandelte Ungleichheit. Zum sozialen Aspekt in der Strafjustiz der Frühen Neuzeit. Geschichte und Gesellschaft, 35. Jg., H. 4, S. 488-533, šeit 488. lpp.

4 Wolfgang Kaschuba (1991). Kommunalismus als sozialer "Common Sense". Zur Konzeption von Lebenswelt und Alltagskultur im neuzeitlichen Gemeindegedanken. Historische Zeitschrift. Beihefte, New Series, Vol. 13, S. 65-91, šeit 78. lpp.

5 Lai gan tieša sakara ar tirdzniecības precēm zvejniekiem nebija, pilsētas vadības dokumentos tos mēdza pieskaitīt pie palīgamatiem.

6 Iekavās norādīts amatu locekḷu skaits 1763. gadā no: Ķemerejas un amatu tiesas saraksts ar amatu locekḷu skaitu [vācu val.], 1763. Latvijas Nacionālais arhīvs - Latvijas Valsts vēstures arhīvs (Rīga, turpmāk: LNA-LVVA), 1382-2-459, 144.-145. lpp.

7 Melita Svarāne (1975). Tirdzniecības palīgamati un to nozīme latviešu topošās buržuāzijas veidošanās procesā Rīgā 19. gs. pēdējā ceturksnī un 19. gs. pirmā pusē. Latvijas PSR Zinātņu Akadēmijas Vēstis, 6, 89.-103. lpp., šeit 91. lpp.

8 Meta Taube (1980). Rīgas latviešu tirdzniecības palìgamati 17.-18. gs. Rīga: Zinātne, 107. lpp.

9 Turpat, 53. lpp.; Paul Johansen, Heinz von zur Mühlen (1973). Deutsch und undeutsch im mittelalterlichen und frühneuzeitlichen Reval. Köln; Wien: Böhlau, S. 127.

10 Jānis Straubergs (1936). Rīgas latviešu pirmās nacionālās cīnas 18. gs. Rīga: A. Gulbis.

11 Taube. Rīgas latviešu tirdzniecības palīgamati 17.-18. gs.

12 Velta Pāvulāne (1966). Koku šķirošana un koku šķirotāji Rīgā feodālisma laikā. Latvijas PSR Zinātņu Akadēmijas Vēstis, 11, 19.-28. lpp.; Ilga Grasmane (1973). Daugava un Rīgas eksports XVIII gs. beigās un XIX gs. pirmajā pusē. Rīga: Zinātne; Svarāne. Tirdzniecības palīgamati un to nozìme latviešu topošās buržuāzijas veidošanās procesā; Melita Svarāne (1980). Pārcēlāju amats Rīgā feodālisma beigu posmā - 18. gs. beigās un 19. gs. pirmajā pusē. Latvijas PSR Zinātņu Akadēmijas Vēstis, 8, 44.-58. lpp.

13 Der Teutschen Sprache Stammbaum und Wortwachs oder Teutsche Sprachsatz (1691). Nürnberg: Johann Hoffmann, Sl. 1054. 

Deutschlands im Zeitalter des Absolutismus. Vierteljahrschrift für Sozialund Wirtschaftsgeschichte, Bd. 67, S. 470; Kaschuba. Kommunalismus als sozialer “Common Sense”, S. 68, 74.

(1981). Formierung der europäischen Gesellschaft in der Frühen Neuzeit. Ein Versuch. Geschichte und Gesellschaft, 7. Jg., H. 1, S. 5-41, šeit 25. lpp.

Georg Ludwig von Maurer (1870). Geschichte der Städteverfassung Deutschlands. Bd. 2. Erlangen: Ferdinand Enke, S. 326, 864; Historisches Archiv der Stadt Köln (Hg.) (1996). Stadtrat. Stadtrecht. Bürgerfreiheit. Ausstellung aus Anlass des 600. Jahrestages des Verbundbriefes vom 14. September 1396. Köln: Druckhaus Locher, S. 101; Kirill Levinson (2000). Chinovniki v gorodakh Iuzhnoi Germanii 16 i 17 vekov: opyt istoricheskoi antropologii biurokratii. Moskva: IVI RAN, s. 12.

Thomas Munck (2007). Keeping the Peace: 'Good police' and civic order in 18th-century Copenhagen. Scandinavian Journal of History, Vol. 32, No. 1, pp. 38-62, šeit 39. lpp.; Jørgen Mührmann-Lund (2016). Good order and the police. Scandinavian Journal of History, Vol. 41, No. 1, pp. 71-90, šeit 72. lpp.

Kaņepāju kulstītāju statūti [vācu val.], 1641. LNA-LVVA, 4038-2-1169, 1.-16. lp., šeit 7. lp.; 1450. gada nastu nesēju statūti [vācu val.], nedatēts noraksts. LNA-LVVA, 4038-2-1084, 33.-35. lp., šeit 35. lp.; 1450. gada sāls nesēju statūti [vācu val.], 1727. gada noraksts. LNA-LVVA, 4038-2-1126, 2.-15. lp., šeit 12.-13. lp.; 1535. gadā izdoti noteikumi liǵgeriem un nastu nesējiem par rīcību ugunsgrēka gadījumā [vācu val.], nedatēts noraksts. LNA-LVVA, 4038-2-1084, 38. lp.

Zvejnieku amata 1606. gada šrāgu noraksts [vācu val.], 1853. LNA-LVVA, 224-1-2679, 1.-8. lp.

Noraksts no 1694. gada loču amata šrāgām un Biržas komitejas piezīmes pie tām [vācu val.], pēc 1816. LNA-LVVA, 4038-2-1084, 23.-30. lp., šeit 25. lp.

Taube. Rīgas latviešu tirdzniecības palìgamati 17.-18. gs., 40.-41. lpp.; Ormaṇu amata statūti [vācu val.], nedatēti, pirms 1765. LNA-LVVA, 1382-2459, 193.-200. lp.

Liǵeru amata statūti [latv. val.]. 10.09.1740. LNA-LVVA, 2222-1-2, 1.11. lp., šeit 8. lp.; Liğeru amata statūti [vācu val.], noraksts, 10.09.1740. LNA-LVVA, 224-1-1207, 221.-234. lpp., šeit 229.-230. lpp. 
27 Rīgas mastu šķirotāju nolikums [vācu val.], 11.07.1776. LNA-LVVA, 40382-1175, 2.-25. lp., šeit 24. lp.

28 Pārcēlāju amata statūti [vācu val.], 01.06.1763. LNA-LVVA, 673-1-822, 1.-15. lpp., šeit 12.-14. lpp.

29 Pārcēlāju amata reglaments [vācu val.], 1798. LNA-LVVA, 4038-2-1084, 3.-33. lp., šeit 4.-5. lp.

30 Ieraksts ķemerejas un amatu tiesas protokolu grāmatā par amatu iesaistīšanu sprādziena seku likvidēšanā [vācu val.], 30.10.1721. LNA-LVVA, 1382-2-544, 324. lpp.

31 Landfogtejas tiesas rīkojums zvejnieku amatam par palīdzības sniegšanu strūgām [vācu val.], 04.05.1805. LNA-LVVA, 224-1-2682, 32. lp.

32 Izraksts no landfogtejas tiesas protokola par sāls nesēju, liǵeru un kaṇepāju kulstītāju lūgumu atbrīvot no šķūtīm [vācu val.], 05.03.1726. LNA-LVVA, 4038-2-1126, 67.-69. lp.; Nevācu amatu vēstule Vidzemes generālgubernatora p.i. valdības padomniekam J. B. Kampenhauzenam par krogegešanas tiesībām [vācu val.], kopija, 12.04.1751. LNA-LVVA, 224-1-1207, 1.-7. lpp., šeit 2.-3. lpp.

33 Izraksts no rātes sēžu protokola par boju izvietošanu [vācu val.], 30.03.1738. LNA-LVVA, 4038-2-1126, 94.-96. lp.

34 Turpat.

35 Izraksti no ķemerejas tiesas protokola par ledus pāḷ izvietošanu Daugavā [vācu val.], 10.01.1737. un 27.01.1739. LNA-LVVA, 4038-2-1126, 97.98. lp.

36 Tagebuch des Ratsherrn Peter von Schievelbein [1687-1771]. In: August von Bulmerincq (1906). Aktenstücke und Urkunden zur Geschichte der Stadt Riga 1710-1740. Bd. 3. Riga: W. F. Häcker, S. 168.

37 Rìgas mastu šķirotāju amata komentāri pie 1776. gada nolikuma [vācu val.], nedatēti. $L N A-L V V A, 4038-2-1174$, 2.-6. lp., šeit 5. lp.

38 Straubergs. Rīgas latviešu pirmās nacionālās cīnas 18. gs., 37.-79. lpp.

39 Justīckolēgijas lēmums strīdā starp Rìgas birğeriem un nevācu amatiem par krogéēšanas tiesībām [vācu val.], noraksts, 13.05.1754. LNA-LVVA, 2715-1279, 19.-20. lp.

40 Tā kā Valdošā Senāta lēmumā par Šteinhauera prāvu daḷēji citēti birgéru argumenti, iespējams izsekot, kādus terminus par attiecīgo jautājumu lietoja krievu valodā. Termins "rab" 18. gs. krievu valodā bieži izmantots kā lūdzēja apzīmējums gan oficiālā, gan privātā sarakstē un mūsdienās vairāk pielīdzināms jēdzienam "kalps", nevis "vergs". Interesanti, ka tieši 18. gs. gaitā Krievijas valdības dokumentācijā vērojama apzināta tendence aizstāt vārdu "rab" ar "poddanij" jeb "padotais", lai attiecības "valsts - padotais" neasociētos ar "kungs - vergs". Sk.: Elena Marasinova (2107). "Zakon" $i$ "grazhdanin" $v$ Rossii vtoroi poloviny 18 veka: ocherki istorii obshchestvennogo soznaniia. Moskva: Novoe literaturnoe obozrenie, s. 331-342. 
41 Viduslaiku izpratnē vārds "Knechtschaft" (kalpība) bija pretējs jēdziens vārdam "Freiheit” (brīvība). Ulrich Meier, Klaus Schreiner (1994). Regimen civitatis. Zum Spannungsverhältnis von Freiheit und Ordnung in alteuropäischen Stadtgesellschaften. In: K. Schreiner, U. Meier (Hg.). Stadtregiment und Bürgerfreiheit: Handlungsspielräume in deutschen und italienischen Städten des späten Mittelalters und der frühen Neuzeit. Göttingen: Vandenhoeck \& Ruprecht, S. 11-36, šeit 18. lpp.

42 Rīgas rātes skaidrojums Vidzemes vicegubernatoram Ludolfam Augustam Bismarkam (1683-1750) strīdā par nevācu tiesībām iegādāties īpašumus pilsētā [vācu val.], kopija, 26.10.1739. LNA-LVVA, 224-1-142, 353.364. lp., šeit 358. lp.; Birǵeru skaidrojums justīckolēgijai strīdā par birǵeru tiesību piešķiršanu Danielam Šteinhaueram [vācu val.], noraksts, 18.11.1748. LNA-LVVA, 224-1-142, 248.-261. lp., šeit 257. lp.

43 Birǵeru skaidrojums Valdošajam Senātam strīdā par birǵeru tiesību piešķiršanu Danielam Šteinhaueram [vācu val.], noraksts, 08.1752. LNALVVA, 224-1-142, 304.-309. lp., šeit 306. lp.; Birǵeru skaidrojums justīckolēgijai strīdā par birǵeru tiesību piešķiršanu Danielam Šteinhaueram [vācu val.], kopija, 12.05.1748. LNA-LVVA, 224-1-142, 262.-272. lp., šeit 264. lp.; Krievijas Valdošā Senāta lēmums par atteikumu piešķirt birǵera tiesības Danielam Šteinhaueram [vācu val.], 23.11.1752. LNA-LVVA, 223-1-81, 2.-2a. lp.; Rīgas abu ǵilžu birǵeru skaidrojums rātei strīdā par krogéēšanas tiesībām [vācu val.], noraksts, 11.06.1751. LNA-LVVA, 224-1-1207, 15.30. lpp., šeit 18., 20. lpp.; Rīgas ǵilžu papildus skaidrojums rātei strīdā par krogēěanas tiesībām [vācu val.], noraksts, 11.12.1751. LNA-LVVA, 224-11207, 146.-180. lpp., šeit 149., 156., 158. lpp.; Valdošā Senāta lēmums Sīmaṇa Raņķa un viṇa biedru lūguma lietā par pierakstīšanu tirgotājos, tulkojums [vācu val.], 10.09.1800. LNA-LVVA, 673-1-565a, 48.-57. lp., šeit 54. lp.; Pārcēlāju amata sūdzība Vidzemes guberņas valdē jauna pārcēlāju reglamenta ieviešanas lietā. Pielikums C. Izvilkums no rātes skaidrojuma Vidzemes kamerālvaldei par nevācu amatiem [vācu val.], kopija, 01.04.1802. LNA-LVVA, 673-1-822, 94.-95. lp.

Daniela Šteinhauera skaidrojums justīckolēgijai, atbildot uz birgeru iesniegumu strīdā par birǵeru tiesību piešķiršanu [vācu val.], kopija, 19.09.1748. LNA-LVVA, 673-1-729, 15.-21. lp., šeit 18.-19. 1p.; Daniela Šteinhauera skaidrojums Valdošajam Senātam strīdā par birǵeru tiesību piešķiršanu [vācu val.], kopija, 1752. LNA-LVVA, 224-1-1207, 374.-391. lpp., šeit 380.-381. lpp.; Nevācu amatu vēstule Vidzemes generālgubernatora p.i. valdības padomniekam J. B. Kampenhauzenam par krogeēšanas tiesībām [vācu val.], kopija, 12.04.1751. LNA-LVVA, 224-1-1207, 1.-7. lpp., šeit 2.-3. lpp.; Nevācu amatu atbilde uz birǵeru vēstuli par krogēěšanas tiesībām [vācu val.], kopija, 10.08.1751. LNA-LVVA, 224-1-1207, 50.-77. lpp., šeit 52., 61., 63. un 69. lpp. 
45 Tomasa Sēḷa skaidrojums Baltijas generālgubernatoram Frīdriham Bukshēvdenam (Buxhöwden, 1750-1811) par sūdzību Valdošajā Senātā jautājumā par pārcēlāju reglamentu [vācu un krievu val.], nedatēts [ap 11.1804.]. LNA-LVVA, 1-2-789, 5.-30. lp., šeit 5.-6. lp.

46 Turpat, 8.-9. lp.

47 Valdošā Senāta lēmums par atteikumu piešķirt birǵera tiesības Danielam Šteinhaueram [vācu val.], 23.11.1752. LNA-LVVA, 223-1-81, 10a., 11. lp.

48 Vidzemes generālgubernatora p.i. valdības padomnieka J. B. Kampenhauzena rezolūcija krogeéšanas lietā [vācu val.], noraksts, 08.01.1753. LNALVVA, 224-1-1207, 276.-293. lpp., šeit 283. lpp.

49 Ligéeru, mērītāju un kaņepāju kulstītāju lūgums rātei apmaksāt pilsētas vārtu bloḳēěanas izdevumus [vācu val.], 26.04.1801. LNA-LVVA, 749-5279, 1.-2. lp., šeit 1. lp.

50 Liğeru, kaņepāju kulstītāju un mērītāju amatu sūdzība rātē par atlīdzības saņemšanu par sabiedriskiem darbiem [vācu val.], 11.09.1801. LNA-LVVA, 749-5-279, 14.-15. lp.

51 Izraksts no fogtejas tiesas sēžu protokolu grāmatas par strīdu starp amatiem un kases kolēgiju par strādnieku darba samaksu [vācu val.], 13.08.1801. LNA-LVVA, 749-5-279, 3.-10. lp., šeit 5. lp.

52 Kases kolẹgijas atzinums amatu apelācijas lietā par darbu apmaksu [vācu val.], 20.11.1801. LNA-LVVA, 749-5-279, 17. lp.

53 Turpat, 6. lp.

54 Fogtejas tiesas atzinums amatu un kases kolẹgijas strīda lietā par strādnieku algu samaksu [vācu val.], 24.08.1801. LNA-LVVA, 749-5-279, 8.10. lp.

55 Rātes spriedums palīgamatu apelācijas lietā pret fogtejas tiesas lēmumu par strādnieku atlīdzības apmaksu [vācu val.], 01.08.1802. LNA-LVVA, 749-62235, 193.-195. lpp.

56 Hildermeier. Bürgertum und Stadt in Russland 1760-1870, S. 130.

57 Tirdzniecības palīgamatu sūdzība Rīgas nolikuma un privilēǵiju izvērtēšanas komitejai [vācu val.], 29.01.1804. LNA-LVVA, 673-1-565a, 2.-19. lp., šeit 9.-15. lp.

58 Kases kolẹgijas aprēķini par maksājumiem mērītāju, lig̣eru un kaṇepāju kulstītāju amatam par darbiem pie vārtiem ledus iešanas laikā no 1798. līdz 1804. gadam [vācu val.], nedatēti [1804]. LNA-LVVA, 673-1-565a, 40.-42., 47. lp.

59 Hildermeier. Bürgertum und Stadt in Russland 1760-1870, S. 131.

60 Rīgas rātes skaidrojums Valdošajam Senātam mastu škirotāju sūdzības lietā par ledus ciršanas darbu uzlikšanu [vācu val.], 08.12.1809. LNA-LVVA, 4-14-372, 16.-21. lp., šeit 17. lp.

61 Vidzemes guberņas valdes ziņojums Valdošajam Senātam par mastu šķirotāju amata sūdzību ledus ciršanas lietā [krievu val.], noraksts, 28.01.1810. LNA-LVVA, 4-14-372, 2.-15. lp., šeit 3. lp. 

7992, 10.-18. lp. iesniegto rēḳinu pareizību [vācu val.], 10.09.1818. LNA-LVVA, 1378-17992, 21.-23. lp. Palīgamatu skaidrojums fogtejas tiesai par rēḳinu pareizību strādnieku apmaksas jautājumā [vācu val.], 19.08.1819. LNA-LVVA, 1378-1-7992, 25.28. lp., šeit 25. lp.

Turpat, 4.-5. lp.

Turpat, 8. lp.

Lig̣eru, kaņepāju kulstītāju, mērītāju un vīna nesēju amatu lūgums fogtejas tiesai par atlīdzības pieprasīšanu no kases kolēgijas par sabiedrisko klaušu veikšanu [vācu val.], 30.09.1808. LNA-LVVA, 749-5-295, 2. lp.

Kases kolēgijas skaidrojums fogtejas tiesai par atlīdzības neizsniegšanu palīgamatiem [vācu val.], 12.11.1808. LNA-LVVA, 749-5-295, 8. lp.

Fogtejas tiesai iesniegti izraksti no amatu instrukcijām [vācu val.], bez datējuma. LNA-LVVA, 749-5-295, 22.-23. lp.

Palīgamatu skaidrojums fogtejas tiesai lietā par atlīdzības saņemšanu par artilērijas pārvadāšanu [vācu val.], 08.01.1810. LNA-LVVA, 749-5-295, 17.-19. lp.

Fogtejas tiesas lēmums palīgamatu un kases kolēgijas strīda lietā par strādnieku atlīdzības apmaksu [vācu val.], 15.04.1811. LNA-LVVA, 749-5-295, 35.-43. lp.

Kases kolēgijas skaidrojums rātei apelācijas lietā par strādnieku atlīdzības apmaksu [vācu val.], 10.01.1812. LNA-LVVA, 749-5-295, 58.-61. lp.

Rātes lēmums kases kolēgijas apelācijas lietā pret palīgamatiem par strādnieku apmaksas atlīdzināšanu [vācu val.], 20.11.1812. LNA-LVVA, 749-5295, 70.-71. lp.

1 Valdošā Senāta spriedums palīgamatu apelācijas lietā strīdā par strādnieku atlīdzības apmaksu [vācu val.], kopija, 06.12.1817. LNA-LVVA, 1378-17992, 5.-9. lp., šeit 5. lp.

Turpat, 7.-8. lp.

Turpat, 9. lp.

Tirdzniecības palīgamatu rēḳini par pieņemtajiem strādniekiem sabiedrisko pienākumu veikšanai [vācu val.], 1807-1818. LNA-LVVA, 1378-1-

Kases kolēgijas sūdzība fogtejas tiesai par tirdzniecības palīgamatu

Kases kolēgijas skaidrojums fogtejas tiesai par nepierādītiem palīgamatu rēḳiniem [vācu val.], 08.01.1820. LNA-LVVA, 1378-1-7992, 32.-35. lp.

Marasinova. "Zakon" $i$ "grazhdanin" v Rossii vtoroi poloviny 18 veka, s. 10. Rīgas landfogtejas tiesas apliecinājums par 710,60 rubḷu banku asignācijās samaksāšanu no artilērijas garnizona līdzekḷiem pārcēlāju amatam par dažādu lietu transportēšanu no kug̣iem uz pilsētu [vācu val.], 31.07.1814. LNA-LVVA, 673-1-822, 140. lp.; Izraksts no Rīgas landfogtejas tiesas protokola par strīdu starp kases kolēgiju un zvejnieku un enkurnieku amatiem 
par plostu tilta izṇemšanu no ledus un nogādāšanu noliktavā [vācu val.], 30.12.1839. LNA-LVVA, 224-1-2682, 44.-45. lp.

80 Ligeru amata lūgums Krievijas imperatoram Nikolajam I par taksu nemainī̌anu [krievu val.], 26.02.1855. LNA-LVVA, 2222-1-1, 10.-12. lp., šeit 10. lp.

81 Rīgas policijas pārvaldes vēstule rātei par zvejnieku pienākumu meklēt slīkoṇus Daugavā [vācu val.], 26.06.1840. LNA-LVVA, 224-1-2682, 47.48. lp.

\section{THE ATTITUDE OF THE RIGA TOWN AUTHORITIES AND THE NON-GERMAN CRAFTSMEN TOWARDS PUBLIC DUTIES FROM THE MID $18^{\mathrm{TH}}$ UP TO THE EARLY $19^{\mathrm{TH}}$ CENTURY}

\section{Anita Čerpinska}

Dr. hist., researcher, Institute of Latvian History, University of Latvia. Research interests: history of Riga in the 18th and 19th centuries.

The paper is dedicated to the public duties in Riga or to these different jobs, which ensured public order and safety. The town authorities assigned nonGerman craftsmen to carry out these duties for free or small reward. The article shows, how often carrying of the public duties is included in the regulations of the crafts, where they are only mentioned, but never clearly explained. There existed no law or one general regulation for setting out all the procedure of realisation of the public duties in the town. But yearly the jobs were assigned and carried out by non-German craftsmen. Starting from the 1730s, the imposition of public duties on the non-German craftsmen was used by the town authorities and burghers as an argument testifying to the inferior status of the members of craft corporations within the town community. In response non-German craftsmen complained about the imposition of these duties and asked to pay for them as for the work.

Key words: onera publica, burgher society of Riga, non-German craftsmen, attitude to work.

The aim of this article is to examine, through the prism of public duties, the attitudes towards this kind of labour held by different strata of Riga society, specifically by the city administration and the non-German craftsmen. The term "public duties" referred to various works undertaken to ensure safety and order, which the town council imposed on the 
non-German craftsmen (timber graders, carriers, ferrymen, fishermen, etc.), to be undertaken for free or for minor recompense. The town authorities considered that they were upholding the rights of these various craftsmen to engage in their profession, thus providing them with a living and welfare, and demanded in return various kinds of service for the benefit of the town.

The article examines how this question is reflected in the regulations and statutes of non-German craftsmen, where they are generally mentioned but not clearly defined. In general, these relate to fires or floods, or to military service. The only detailed description of public duties is to be found in the 18th-century regulations of ferrymen. Here, the town has tried to set out which kinds of work are to be paid from the town treasury and which are to be performed without remuneration. This is at a time when the town had already seen several disputes with the crafts corporations over the allocation of work.

Although there are no documents setting out the procedure for the performance of such duties in the town, they were imposed every year and discharged to a greater or lesser extent by the craftsmen. Public duties could be extraordinary or regular in character. Extraordinary duties generally involved dealing with the consequences of some disaster. Regular duties had to do with safety and order in the town, many of them concerned with safe travel along the River Daugava. In the absence of special services, craftsmen fulfilled policing and lifesaving functions. Most of the craftsmen were involved in the annual work of building and removing the raft bridge.

Starting from the 1730s, imposition of public duties on non-German craftsmen was used by the town authorities and burghers as an argument testifying to the inferior status of the members of the craft corporations within the town community. When they addressed the provincial authorities or state institutions, burghers strove to dissociate their community entirely from the non-burgher community, and moreover they would do so not only with respect to their contemporary time, but also to that of previous centuries. According to their interpretation, non-Germans were totally excluded from all the privileges of the burghers as being not worthy to enjoy them, since they were performing unpaid labour corresponding to the status of servants. It is also observed that in their replies craftsmen gave relatively little attention to public duties, apart from the issue of tavern-keeping, which is dealt with at greater length, possibly in response to the extensive treatment of this question by the burghers in their documents. 
The last part of the article examines complaints by the craftsmen addressed to authorities regarding the imposition of duties, with requests for remuneration. In these conflicts, in contrast to disputes regarding the status of particular social strata, the town authorities regarded public duties as unpaid work. On the other hand, the arguments brought by non-German craftsmen indicate that they perceive a connection between unpaid work and non-free status, and accordingly they present a strict demand for remuneration. Significantly, craftsmen emphasised that their members were taxpayers, which in their view freed them from public duties. It is not entirely clear whether the attitude on the part of the craftsmen towards public duties had been affected by the "spirit of the age" or by previous disputes regarding rights in the town.

Even after the disputes over remuneration for public duties, the town managed to preserve a certain status quo concerning this issue. Documents from the first half of the 19th century testify that the auxiliary trade craftsmen continued to fulfil the duties imposed on them but received remuneration for undertaking particular services for the benefit of the state or the town. There is also evidence that some work continued to be undertaken without remuneration. Accordingly, the question of public duties did not disappear from the life of the town, but the absence of vociferous conflicts indicates that the town authorities and craftsmen had succeeded in reaching a compromise and had agreed on how to implement it. Apart from this, in the course of the 19th century, the role of the auxiliary trade craftsmen progressively lost its importance, along with the development of the police, fire-fighters and other services. 